\title{
O FANTÁSTICO NA LITERATURA: CONTOS MEDIEVAIS E OITOCENTISTAS
}

\author{
THE FANTASTICAL IN LITERATURE: MEDIEVAL AND EIGHTEENTH CENTURY TALES
}

\author{
Manoel Francisco Guaranha ${ }^{1}$ \\ Alzira Lobo de Arruda Campos ${ }^{2}$ \\ Álvaro Cardoso Gomes ${ }^{3}$
}

\begin{abstract}
RESUMO: Contos medievais e oitocentistas apresentam-se como visões estereotipadas dos momentos históricos em que foram produzidos, espelhando incertezas e temores coletivos a respeito de um presente ameaçador, visualizado por seus autores, protagonistas dos cenários histórico-sociais nos quais exercitaram a sua imaginação. Neste artigo, procuramos definir o papel desempenhado pela literatura e pela história na grande aventura de se compreender o homem em suas incursões no mundo real e no imaginário, registradas em contos categorizados como "fantásticos". Como suportes empíricos e com uma abordagem interdisciplinar, figuram em primeiro lugar, neste estudo, os contos medievais, destinados a cumprir funções sociais de alto valor operatório para os camponeses. Compõem o segundo bloco empírico os contos fantásticos do século XIX organizados em antologia por Ítalo Calvino. Este estudo situa-se na longa duração e pretende surpreender, na trama narrativa dos contos, a realidade e o fantástico de personagens, além das circunstâncias e visões culturais da época em que foram produzidos. Ao comparar narrativas criadas por camponeses pobres a outras produzidas por literatos integrantes da média burguesia, procuramos contribuir para o entendimento das condições de produção entre ambos os blocos e das circunstâncias histórico-sociais que uniram o fantástico camponês ao fantástico urbano das sociedades pós-industriais.
\end{abstract}

Palavras-chave: Ficção e realidade; fantástico e literatura; contos medievais e oitocentistas.

ABSTRACT: Medieval and eighteenth century tales are like stereotyped visions of historical moments in which they were produced, mirroring collective uncertainties and fears about a threatening present, viewed by its authors, main characters of socio-historical scenarios in which they exercised their imagination. In this paper, supported by these theoretical suppositions, we seek to define the role played by literature and history in the great adventure of understanding men in their incursions in the real and imaginary world, registered in tales categorized as "fantastical". As empirical bases and with a multidisciplinary approach, are in first place, in this study, the medieval tales, destined to fulfill social questions of an extremely high operatory value to the peasants. The second empiric block is composed by the fantastic tales of the XIX century, organized in an anthology by Ítalo Calvino. This study is of long duration and intends to surprise, in the narrative plot of the tales, the reality and fantastical of

\footnotetext{
${ }^{1}$ Doutor em Letras (Literatura Portuguesa) pela Universidade de São Paulo-USP. Professor das Faculdades de Tecnologias de Santo André e do Ipiranga-FATECs e professor do Programa de Mestrado em Ciência Humanas da Universidade de Santo Amaro-UNISA

2 Doutora em História Social pela Universidade de São Paulo-USP. Livre-docência em Metodologia da História, pela Unesp. Professora do Programa de Mestrado Interdisciplinar em Ciências Humanas da UNISA.

3 Professor Titular da Universidade de São Paulo-USP e da Universidade Santo Amaro-UNISA. Doutor em Letras (Literatura Portuguesa), livre-docência pela mesma Universidade. Pós-doutor em Portugal e nos Estados Unidos. Visiting Professor na University of California Berkeley e Visiting Writer no Middlebury College. Professor de graduação e pós-graduação e Coordenador do Mestrado em Ciências Humanas da Universidade Santo AmaroUNISA.
} 
characters, beside the circumstances and cultural visions of the period they were produced. Upon comparing the narratives created by lower class peasants and others produced by literate integrants of the bourgeois class, we seek to contribute to the understanding of the conditions of productions between both block and the historical-social circumstances which linked the fantastic tales of the peasants to the fantastic urban tales of the post-industrial societies.

Key-words: Fiction and reality; the fantastical and literature; medieval tales and eighteenth century people.

\section{Introdução}

Este estudo situa-se na longa duração e pretende surpreender, na trama narrativa dos contos, a realidade e o fantástico de personagens, além das circunstâncias e visões culturais da época em que foram produzidos. Ao comparar narrativas criadas por camponeses pobres a outras produzidas por literatos integrantes da média burguesia, procuramos contribuir para o entendimento das condições de produção entre ambos os blocos e das circunstâncias históricosociais que uniram o fantástico camponês ao fantástico urbano das sociedades pós-industriais. Os laços multisseculares estabelecidos entre as duas produções podem ser identificados até na expressão "ficção gótica" usada como uma categoria literária que reúne Frankenstein a Drácula, dois monstros, isto é, criaturas em "transformação", localizadas por seus autores, Bran Stoker e Mary Shelley, nos umbrais entre a vida e a morte, nos quais realidade e alucinação apresentamse indiscerníveis. O "gótico", termo que remete diretamente à Idade Média, retraduz o horror à morte que apareceu no crepúsculo daquele longo período de mil anos para um medo revestido de roupagens científicas - históricas ou biológicas - do cientificismo europeu do século XIX. Nesses termos, a abordagem religiosa da morte, acompanhada pelo medo ao além-túmulo, continua presente, mas se aclimata aos progressos da ciência e do momento histórico em que viveram os seus autores.

Ao tomar como universo empírico a literatura presente em contos produzidos na Idade Média e no século XIX, procurando observar as permanências e mudanças no estilo cognominado de "fantástico", estamos preocupados em estabelecer as distinções possíveis entre épocas históricas díspares, observáveis em suas produções literárias. $\mathrm{O}$ diacronismo revela-se com facilidade. De um lado, há uma sociedade camponesa marcada por relações de ordem entre servos e vilões, dominados pelos senhores feudais, detentores de benefícios no campo e nas cidades. Estas, incipientes, só começaram a se desenvolver a partir do comércio, nos estertores do século XII, mas continuaram como um subproduto da economia rural. Do outro lado, situase uma sociedade capitalista, com profundas mudanças trazidas pela Revolução Industrial de meados do século XVIII e pela Revolução Francesa de 1789, que se seguiu à primeira. Contrapostos, o mundo obscurantista medieval, dominado pela Igreja e pelos senhores da guerra, e o mundo iluminista do capital, dos operários organizados em movimentos políticos, da substituição do Ancien Regime pela sociedade de classes, pelo individualismo que substituiu o coletivismo anterior e que apresentou a grande novidade de içar as classes do trabalho à boca de cena.

Essas sociedades tão dessemelhantes em suas estruturas e espaços cronológicos exerceram o seu imaginário na literatura, por meio de contos que aqui se analisam, procurando 
ver as relações que mantiveram com as realidades e o imaginário coletivos. Avaliam-se esses contos como visões estereotipadas das épocas históricas em que foram produzidos e como espelhos das incertezas e temores coletivos a respeito de um presente ameaçador. Os autores, por sua vez, são vistos como testemunhas dos cenários histórico-sociais em que viveram. Advirtase que esta não é uma investigação sobre "a lógica do delírio" encontrada na ficção que mergulha "de maneira categórica no mundo do fantástico, do pleno desvario, da magia", articulando imagens nascidas do delírio e construindo imagens que desembocam em mistérios desafiadores às tentativas de os compreender. Entretanto, mesmo os mistérios mais impenetráveis fornecem algumas chadves para a sua decodificação, "como se o mistério valesse como uma iluminação oculta por detrás de um véu, cuja função seria a de entreabrir, aos olhos dos curiosos, a porta de um universo fora do comum, só acessível a iniciados" (GOMES, 2017, p. 26). A análise dos mistérios inscritos nos contos fantásticos permite-nos entreabrir a porta de um universo, cujos aspectos fora do comum apresentam, em negativo, imagens do cotidiano de homens e sociedades há muito desaparecidos. Embora a "lógica do delírio" acima apontada não esteja ausente desta investigação, ela é tomada como um dos elementos inscritos na rede mágico-religiosa que prendia a imaginação dos autores do passado, como uma das visões possíveis do momento histórico que registraram.

\section{Metodologia}

Como conceito básico, considera-se "imaginação" como decorrente de um imaginário coletivo, que se confunde com a história das mentalidades, sobre a qual se pergunta se compreende uma realidade científica, se apresenta uma coerência conceitual, se é epistemologicamente operatória para o entendimento das dimensões individuais ou coletivas das narrativas. Com esses objetivos, procuramos definir o papel desempenhado pela literatura e pela história na grande aventura de se compreender o homem em suas incursões no mundo real e no imaginário, registradas em contos categorizados como "fantásticos". Nessa linha de reflexão, consideramos que o contexto esclarece e explica o fantástico como fator estruturante da realidade, mas não como fator único uma vez que o tempo e o espaço históricos são multifacetados, compondo um pluralismo estrutural que deve ser avaliado em seu conjunto. Entendemos, como Darnton, que a história das narrativas (e dos livros) inscreve-se como uma nova disciplina das "ciências humanas", permitindo uma visão mais ampla da literatura e da história da cultura em geral (DARNTON, 1998, p. 13).

$\mathrm{Na}$ categoria de suportes empíricos e com uma abordagem interdisciplinar, figuram em primeiro lugar, neste estudo, contos medievais, erroneamente chamados de "infantis", uma vez que se destinavam a cumprir funções sociais de alto valor operatório para os camponeses. Os seus autores permanecem individualmente anônimos, enquanto que as suas origens, definidas com relativo rigor, remontam ao século XIII. Após cinco séculos, o desenvolvimento dos estados nacionais, aliado à primeira explosão demográfica da história e à ameaça recorrente da eclosão de revoluções proletárias, provocou grande interesse pelo conhecimento do "povo", resultando no surgimento do folclore, uma nova disciplina das Humanidades, e em seus agentes, os "folcloristas", que passaram a recolher "contos populares", reescrevendo-os em versões afeitas aos 
gostos dos salões, chamadas, a partir de então, de "infantis". Nessa empreitada, destacaram-se Charles Perrault, Hans Christian Andersen e os irmãos Wilhelm e Jacob Grimm, cujos contos compõem o primeiro elemento comparativo desta análise. Os contos fantásticos do século XIX, organizados em antologia por Ítalo Calvino, compõem o segundo bloco empírico.

\section{O fantástico no mundo real e no imaginário: contos e mitos}

Contos e mitos fazem parte dos objetos da história das mentalidades, entendida como uma história social que vai aos limites extremos da realidade, isto é, aos seus símbolos, por meio dos quais nós entendemos as pessoas e as coisas do universo. De acordo com Jacques Le Goff, a primeira atração da história das mentalidades reside precisamente em sua imprecisão, em sua vocação a designar os resíduos da análise histórica. Em Homens e mulheres da Idade Média, Le Goff penetra no âmbito operatório do imaginário, ao recorrer a personagens da história imaginária, "pois numa sociedade o imaginário tem seguramente tanta importância e eficácia quanto as condições reais da vida e do pensamento" (LE GOFF, 2013, p.11). No seu entendimento, as grandes figuras da Idade Média são de naturezas diversas. Algumas, flagrantemente históricas, só marcaram suas épocas e permaneceram na memória ao se transformar em mito, como o rei Arthur, o cavaleiro Roland e Robin Hood. Outras são personagens da religião cristã, desempenhando na vida cotidiana um papel que fazia agir na terra o elemento sobrenatural. Satã do lado do mal e a Virgem Maria do lado do bem compõem o pensamento dualista ocidental que considerava a vida humana como uma grande luta entre o Bem e o Mal. As personagens são vistas como testemunhas de sua época, dela apresentando uma imagem estereotipada (LE GOFF, 2013, pp. 11-13).

$\mathrm{Na}$ análise de personagens de tal forma polarizadas torna-se essencial o uso de um artifício metodológico já intitulado de "peneiramento" por meio do qual as narrativas são submetidas a uma clivagem que deve levar ao conteúdo nelas inserido. $O$ termo clivagem, no sentido original do francês de "fender", é compreendido como separação, diferenciação ou oposição entre duas ou mais coisas quaisquer. Quando aplicado ao maravilhoso, mostra que a fenda entre o real e o sobrenatural tende a exercer diferentes funções operatórias, sociais e culturais, como elemento epistemológico organizador do imaginário, com vistas a dar conta daquilo que não se pode compreender, a partir do exercício da razão, até se chegar a uma realidade vivida ou a uma realidade narrada. Estamos, portanto, diante da história quase parada das mentalidades, um território ainda inexplorado, que Darnton considera poder ser chamada de história cultural, por tratar de nossa civilização da mesma maneira como os antropólogos estudam as culturas exóticas. Portanto, uma história de tendência etnográfica. $\mathrm{O}$ historiador etnográfico estuda a maneira como as pessoas interpretavam o mundo, conferiam-lhe significado e infundiam-lhe emoção (DARNTON, 1986, pp. XIII-XIV).

Ao pensar, interpretar, conferir significado e infundir emoção ao mundo, as pessoas não distinguiam o real e o imaginário de suas existências, como fazem os estudiosos das narrativas literárias, que usam dessa distinção como um artifício metodológico. Com efeito, as estruturas do mundo real mantêm espantosas correspondências com as estruturas mentais, que se apresentam, em geral, como tributárias das primeiras. As relações entre conto e mito, na 
clivagem entre realidade vivida e realidade transposta da narrativa, têm provocado polêmicas frutíferas para o esclarecimento de um problema ainda em fermentação.

Quanto a mito, Mircea Eliade considera tratar-se de uma história verdadeira que se passou no começo do Tempo e que serve de modelo aos comportamentos dos humanos. $\mathrm{O}$ mito é a revelação de um acontecimento primordial que fundou, seja uma estrutura do real, seja um comportamento humano. A expressão "história verdadeira" não diz respeito a uma verdade histórica, mas a uma verdade anterior à História. Dentre as missões do mito está a de transmitir, sob a forma imaginada, as experiências humanas básicas, das quais juventude, vida e morte (esta, contendo o nascimento) constituem os temas essenciais. Quando o mito passa para a literatura, torna-se conto ou lenda, degrada-se e obscurece-se, não se assumindo mais como uma revelação de "mistérios". Pode-se aventar que a exploração literária ou artística do mito só se torna possível a partir do momento em que a "experiência" mítica desapareceu. Ao procurar aprofundar as imbricações entre conto e mito, não damos aos monstros a importância que têm para as narrativas de viagem embora impliquem um certo número de funções mentais solicitadas igualmente pelos dois conceitos (Kappler, 1980, p. 78). Com efeito, a inserção das narrativas de viagem, como novas categorias literárias, demandariam um esforço teóricometodológico incabível no espaço reservado a um artigo.

As interpretações acima, que se utilizam dos contos infantis como evidências simbólicas presentes da teoria freudiana, é contestada radicalmente por Darnton, em "Histórias que os camponeses contam: o significado de Mamãe Ganso", que assume posição central da hermenêutica sobre contos de fadas. O pensamento de Bettelheim considera que os contos agem ao nível duplo do consciente e do inconsciente, colocando em cena objetos e personagens que evocam associações muito diversas de seu significado aparente.

Contos e mitos apresentam certo número de procedimentos descritivos e de temas que também se encontram nas narrativas de viagens. A distinção entre conto e narrativa de viagem apresenta alguns fundamentos. $\mathrm{O}$ conto poderia ser distinguido pela intensidade da expressão e da intenção míticas, transmitindo um conjunto de experiências míticas ou arquetípicas sob uma forma concentrada. Raramente se encontra no conto a preocupação em distinguir o maravilhoso da realidade, uma vez que esses dois conceitos significam um só, ou pelo menos estão indissoluvelmente ligados pela existência de seres ou objetos mágicos que os colocam em contato constante. O conto oferece o maravilhoso-real em estado puro (KAPPLER, 1980, p. 81). Até o século XV, a clivagem entre o real e o irreal não se havia operado: tudo era realidade.

Existem casos em que o mito e a realidade não são categorias antagônicas: as civilizações nas quais a magia ocupa um lugar oficialmente reconhecido é um exemplo. Nas sociedades xamânicas, a "viagem" do Xamã é uma viagem real: ele desce efetivamente aos Infernos, ele se metamorfoseia realmente em lobo ou em outro animal mágico, tudo o que lhe acontece no outro mundo é considerado como autêntico: os espectadores não o podem ver com os seus olhos, mas eles o testemunham pela dança do Xamã, pela música, canto, ritmos do tambor e diferentes estados físicos e nervosos (o transe) pelos quais passa o Xamã sob os olhos da assistência (KAPPLER, 1980, p. 64). Em outros casos, o mito é revivido periodicamente pela comunidade inteira sob a forma de festa. A magia é um domínio em que tudo é possível. Ela confere ao mágico um poder sobre todo objeto, sobre toda criatura. A magia é como o eixo 
vertical que transpassa o universo, do Inferno ao Paraíso: ela põe em relação todas as forças, todos os seres que, sem ela, seriam confinados na sombra e no isolamento (KAPPLER, 1980, p. $65)$.

Contos e mitos, na clivagem entre realidade vivida e realidade transposta da narrativa são encarregados de exprimir um conjunto de estruturas humanas e sociais fundamentais. $\mathrm{O}$ que faz o mundo avançar, levando-o a substituir a imobilidade primitiva pelo movimento e o progresso, é uma separação inicial: separação do céu e da terra nos mitos cosmogônicos, separação de Deus e dos homens. Dessa separação decorre um estado instável entregue à sorte das aventuras, mas sobre o qual o homem conserva um certo controle. Alguns temas são mais aptos do que outros para manter em equilíbrio o ponto de contato entre os três domínios mitoconto-realidade. Podemos, como exemplo, constatar que as narrativas de viagens possuem um conteúdo mais "realista".

Embora o real e o vivido, de um lado, e o maravilhoso, o fantástico e o sonhado, de outro, apresentem-se, num primeiro momento, clivados ou irremediavelmente separados pelo aspecto sensorial, que concede categoria de verdade ao factual, e pelo aspecto imaginativo, que confere o caráter ficcional, fingido, ao narrativo, essas categorias são, por assim dizer, conectadas pelos processos literários, especialmente por aqueles que se denominam como maravilhosos ou fantásticos. Para tanto, num primeiro momento discutiremos o maravilhoso e suas manifestações no mundo medieval, bem como a evolução das funções dessa modalidade e, num segundo momento, as funções do fantástico na sociedade oitocentista.

\section{Ficção e realidade histórica nas narrativas literárias}

A Idade Média criou narrativas imaginárias destinadas a alimentar sonhos/pesadelos de longa duração, na maior parte das vezes por meio da sublimação das realidades sociais e materiais daquela época. As narrativas contadas por camponeses podem ser acompanhados em avatares do imaginário fantástico oitocentista, com base em autores, como José Paulo Paes, que analisa as dimensões do fantástico, observando as ressignificações desse conceito, bem como o amálgama entre o fantástico e o maravilhoso, para chegar à função terapêutica daquele gênero na contemporaneidade: propiciar ao leitor um meio de escape a uma "realidade cada vez mais codificada e limitadora", por meio de um jogo com a verdade. (PAES, 1985, p. 192).

Entendemos que a clivagem entre a realidade vivida e a narrada opera, justamente, na consciência do leitor como um modo de compreender, ou pelo menos relativizar, os inimagináveis vãos entre o céu, o inferno e a terra. Esse universo sobrenatural compõe-se de representações metafóricas do nosso inconsciente que constituem a face especular da realidade presa à lógica de uma física cujas leis ainda estão sub judice das eventuais descobertas científicas propiciadas pelos avanços tecnológicos que se multiplicam no mundo contemporâneo. Daí decorre que o maravilhoso e o fantástico sejam contextuais: o que já foi fantástico em um Júlio Verne, por exemplo, tornou-se realidade graças a avanços tecnológicos.

Por outro lado, o fantástico pode ser considerado como um jogo entre a ficção e a realidade, configurando ações voltadas para testar as fronteiras da verdade, gênero em que Paes detecta como denominador comum a oposição diametral entre a realidade vivida e a imaginada. 
Nesse sentido, Paes dialoga com Eric S. Rabkin, para quem o fantástico é o espanto que sentimos pela súbita inversão das regras de base do mundo narrativo, "mundo feito de palavras [...] que se propõe a ser uma imitação ou um equivalente do mundo real” (PAES, 1985, pp. 184185). Tal inversão no mundo da normalidade e da realidade estende-se a outros gêneros, como às ficções policiais e científicas e aos contos de fadas. Paes adverte, contudo, que há certas distinções entre os primeiros gêneros, em que a inversão da realidade pode ser explicada pela lógica investigativa ou pela lógica científica, e os segundos, em que a surpresa dilui-se no convencionalismo do mundo imaginário dos seres feéricos: "o fantástico, por ocorrer no seio do próprio cotidiano, afeta-o e põe em dúvida o nosso mesmo conceito de realidade”. (PAES, 1985, p. 186).

As considerações de Paes incluem, ainda, Tzvetan Todorov, autor que restringe o fantástico a um terreno distinto do maravilhoso, do conto de fadas e do estranho, ou seja, àqueles fatos para os quais se tem uma explicação prévia à conclusão da narrativa. $O$ fantástico para Todorov reside na hesitação que o leitor possui ao considerar o mundo da narrativa como mundo próximo ao real, ao explicar o fenômeno de modo natural ou sobrenatural. Paes observa que a delimitação proposta por Todorov, embora abarque grande parte dos contos rotulados como fantásticos, não comporta o mundo literário criado por Kafka, Borges ou Cortázar, para o qual ao leitor "não resta outra alternativa que não seja a de aceitar em si e por si esse fantástico universo ficcional, sem mais se preocupar em cotejá-lo com o universo real" (PAES, 1985, p. 188). Nessa mesma vertente, Jean-Paul Sartre comenta que os textos de Kafka transformam a nossa razão, que originariamente deveria endireitar o mundo, em algo fantástico (PAES, 1985, p. 189). A partir dessa observação, Paes considera que, ainda que tenha recorrido à tradição folclórica e mesmo mitológica da antiguidade, a literatura fantástica, tal qual a concebemos hoje, tem origem histórica no século XVIII com a preocupação maior de "pôr em xeque o reacional do que o real propriamente dito" (PAES, 1985, p. 189), como à época das Luzes ou ao século do racionalismo baseado no princípio de que o filósofo não podia admitir nada sem prova: "Foi precisamente contra os excessos dessa tirania da razão - responsável, no campo das artes, por uma fria elegância formal onde não havia espaço para a expressão dos desejos, anseios ou temores mais obscuros da alma humana - que se voltou a literatura fantástica" (PAES, 1985, p. 190).

A característica da literatura fantástica, que contesta "a hegemonia do racional fazendo surgir no seio do próprio cotidiano por ele vigiado e codificado, o inexplicável, o sobrenatural o irracional, em suma" (PAES, 1985, p. 190), estende-se para o Romantismo que se opõe à objetividade da arte neoclássica e, finalmente, ao Realismo-Naturalismo de caráter positivista, racional e objetivo, sustentado pela visão da ciência e da técnica.

O século XX, por sua vez, acompanha a derrocada da Ciência frente à infalibilidade que lhe fora atribuída no século XIX, bem como a disposição dessa forma de conhecimento em investigar fenômenos antes considerados irracionais como o inconsciente e até paradoxais como o de antimatéria (PAES, 1985, p. 191). Essa fluidificação das fronteiras da racionalidade trazida, paradoxalmente, pela racionalidade científica, longe de anular as funções do fantástico, veio libertar, por fim, o fantástico de seus antigos compromissos. Dessa forma, resolveu-se a antiga hesitação entre o natural e o sobrenatural por meio da proibição da visada metafórica ou 
alegórica e o fantástico passou a gozar de plena liberdade para desenvolver no homem o sentido do mistério de si mesmo e do mundo. O texto literário passou a ser lido como uma imagem invertida e substituta da realidade, por meio do qual se ingressa em uma suprarrealidade, na qual "sonho e desejo, banalizado um pela decodificação psicanalítica, sufocado outro pelas crescentes coerções sociais, retomam a plenitude de seus direitos." (PAES, 1985, p. 192).

Desse ponto de vista, parece ser possível atar as pontas do maravilhoso medieval às do fantástico contemporâneo por meio do conceito da clivagem que essas categorias propõem entre o real e o narrado, cuja função reside em um movimento especular na tentativa de estabelecer mais do que um "jogo com o medo", apontado por Roger Caillois (Apud: PAES, 1985, p. 191), um jogo com a verdade (PAES, 1985, 192), seja a verdade dogmática do cristianismo medieval, seja a verdade do racionalismo do século XVIII, seja a verdade científica do século XIX, estas últimas, aliás, não menos dogmáticas. É, portanto, na clivagem entre o real e o narrado que se estabelece a ponte entre o maravilhoso e o fantástico. Ponte tênue, é bem verdade, mas capaz de ligar os dois universos que, antes de serem opostos, apresentam-se como complementares e especulares no sentido em que ambos se encontram refletidos e não refratários, como pode parecer em um primeiro momento. O maior perigo que ameaça esse tipo de abordagem é evidentemente o de não conseguir identificar os limites entre épocas que comportavam ideologias, atitudes mentais e comportamentos sociais muito diferentes entre si e de nós próprios, como seus observadores (ROBIN, 1973, p.66).

Tendo-se em conta essas premissas, é possível afirmar com o rigor analítico possível que o contexto esclarece e explica o fantástico dos contos, como fator estruturante da realidade. Para os contos medievais, o cenário é fundamentalmente rural, povoado por camponeses pobres, famintos e desesperados perante as calamidades múltiplas que os assolavam: os rigores do clima, a exploração quase inconcebível dos senhores feudais, a fome, a doença e a morte. Desse ambiente, fazem parte fundamental os animais, fontes de sobrevivência e de convívio. Seja como bichos de estimação, de carga no trabalho ou de caça no espaço reservado e de prestígio do grupo senhorial, os animais fornecem alimentos e condições de existência aos homens, ocupando territórios iguais ou contíguos a suas casas. A esta familiaridade concreta justapõe-se uma intensa vida simbólica. O mundo animal reflete toda a vida moral dos homens: para eles, o animal constitui um instrumento essencial de medo ou prazer, danação ou salvação (LE GOFF, 2009, p. 235).

Os animais domésticos e selvagens são onipresentes nas histórias contadas por camponeses. Os primeiros têm no gato uma das personagens mais assíduas às narrativas. Num dos estereótipos mais conhecidos, o gato é deixado como única herança ao filho mais novo por princípio, o melhor e o mais inteligente da prole. Como decorrência da regra de primogenitura, é a ele que compete desenvolver estratégias de sobrevivência, mais do que a seus irmãos mais velhos. Destituído de herança, o cadete é lançado à estrada, em busca da sorte, acompanhado por poderes mágicos, exercidos por ações propiciatórias junto a personagens que se apresentam durante a caminhada. Trata-se, pois, de uma narrativa compensatória: a falta de poderes de personagens marcados pela pobreza e miséria encontra-se equilibrada, no campo narrativo, por poderes extraordinários atribuídos a figuras do cotidiano camponês. É esse o tema central do conto "O Gato de Botas", herdado pelo filho desprovido, e que conduz o seu 
dono, por meio da esperteza e do engano, ao melhor e mais improvável dos destinos: casar-se com a princesa herdeira do trono de seu reino. À evidência, trata-se de uma circunstância absolutamente insólita de uma sociedade em que as pessoas nasciam e morriam na mesma ordem a que pertenciam seus pais. Em torno do insólito, fortemente ancorado no fantástico, a dura realidade vivida por servos e vilões é retratada. Contra a fome, a guerra e a morte, os três flagelos que atingiam os pobres medievais, restava a fuga para as estradas. Contra as imensas injustiças sociais, restava uma estratégia composta por astúcias, espertezas e mentiras, igualmente presente nas narrativas.

A mistura de formas ou de atributos de animais "inferiores" ao homem, vale-se na maior parte dos folclores, com alta frequência, da raposa, encarnando nela desvios morais do malandro e do enganador. Renart, o raposo, por exemplo, é uma das criações mais originais da Idade Média, exprimindo a natureza complexa das relações entre os homens e os animais (LE GOFF, 2009, pp. 234-235). Além da artimanha e ambiguidade de seus significados fundamentais, a raposa liga-se a duas relações significativas no imaginário europeu medieval: ele tem um adversário no lobo e não pode ser dissociado da sociedade feudal monárquica. No interior dessa sociedade, a raposa, sempre complexa e ambígua, estabelece uma relação privilegiada com o leão, como seu vassalo e serviçal, ou como o seu contestador e usurpador. (LE GOFF, 2009, p. 235). O cão, o primeiro animal a ser domesticado pelo homem, também se apresenta, mas nas suas qualidades de súdito, devendo lealdade, proteção e trabalho ao seu dono/suserano. Mas também estão presentes os animais selvagens, dentre eles avultando o lobo, que compõe um dos medos coletivos que assaltavam o homem no passado. Entre os animais nocivos, o lobo era o mais temido, visto como misterioso - por viver nos bosques -, além de se apresentar terrivelmente nas épocas em que a penúria se instalava nas aldeias. Com efeito, em períodos de grande fome os lobos atacavam os camponeses em suas cabanas, matando homens e animais domésticos. Nos contos e fábulas o lobo aparece como um sinal de grande perigo. Para o inconsciente coletivo, talvez significasse a encarnação do emissário sombrio do mundo subterrâneo. No campo das representações conscientes, aparecia como o inimigo dos homens e dos rebanhos, como companheiro da guerra e da fome. Não é de admirar que os relatos sobre licantropia se tornassem corriqueiros na passagem do século XVI para o XVII e que os gritos de "Lobo! Lobo!" ressoem com frequência na literatura popular (DELUMEAU, 2009, p. 102-104).

No imaginário do povo "miúdo", o maravilhoso não demarca apenas a fronteira entre o real e o sobrenatural, entre o vivido e o narrado, dificultando que se possam discernir as maravilhas provenientes da magia diabólica dos verdadeiros milagres e das maravilhas naturais criadas por Deus (LE GOFF, 2002, p. 105). O maravilhoso parece constituir a linha narrativa que une o homem e Deus, o homem e a natureza e o homem e o Diabo, na medida em que "misturava objetos de admiração e de veneração com objetos de perdição, transpondo a distinção entre o real e o verdadeiro, de um lado, e o ilusório e o falso, de outro" (LE GOFF, 2002, p. 105). Na Idade Média, o maravilhoso constitui-se de um conjunto de fenômenos que incluem seres e objetos cuja característica é a de serem surpreendentes, podendo ser associados quer ao domínio propriamente divino, próximo ao milagre portanto, quer ao domínio natural, que considerava a natureza como o produto da criação divina, quer ao domínio mágico, 
diabólico, entendendo este como uma ilusão produzida por Satã e seus seguidores sobrenaturais ou humanos (LE GOFF, 2002, p. 106).

Embora não se possa confundir o maravilhoso medieval com o fantástico contemporâneo, que surge como um gênero literário a partir do Romantismo ligado ao surpreendente e ao incrível (LE GOFF, 2002, p. 106), essas categorias estão relacionadas, em certo sentido, como a visão de algo que desafia a razão, a lógica da natureza. O termo maravilhoso é derivado da raiz mir, também encontrada nos termos latinos miror, mirari, e se caracteriza pelo espanto que suscita, em geral admirativo (LE GOFF, 2002, p. 106-107). O termo latino speculum, substituído na língua vernácula por miroir, a partir do século XII, remete a um gênero literário-didático concernente a um domínio do saber concebido como uma concepção especular do universo científico, atinente também ao campo das maravilhas. "O homem contempla a Criação em um espelho, incluindo o que ela encerra de surpreendente, de extraordinário" (LE GOFF, 2002, p. 107).

No mundo medieval, a desconfiança e a hostilidade provocadas pelas sobrevivências do paganismo geraram a ocupação do espaço do maravilhoso na existência humana pelos milagres divinos, intermediados pelos novos heróis ou santos. Já a partir do século XI em diante, notadamente na passagem do XII para o XIII, o miraculoso de origem divina e o mágico da natureza diabólica separaram-se, tendo surgido um intermediário propriamente terreal, natural: o maravilhoso propriamente dito (LE GOFF, 2002, p. 108). Nesse ponto, "maravilha” ficou delimitada a fenômenos que, embora naturais, escapam à compreensão humana. Finalmente, entre os séculos XIV e XV, o fenômeno ganha espaço no mundo literário, estilizando-se: "o maravilhoso torna-se mais literário do que religioso" (LE GOFF, 2002, p. 108).

Essas ideias apresentam-se na exegese pluralista e interdisciplinar dos contos medievais, na qual é possível distinguir duas correntes principais: a psicanalítica e a histórica propriamente dita. A primeira conseguiu sucesso no mundo pós-freudiano ao enfatizar o caráter terapêutico dos contos para o desenvolvimento equilibrado das crianças, consideradas sempre com as mesmas necessidades psíquicas, independentemente da época em que viveram - crianças míticas, por assim dizer. Essa interpretação, baseada em símbolos escondidos, motivos inconscientes e mecanismos psíquicos, é asperamente criticada pelos historiadores, entre os quais figura Darnton (1986), que contesta o monismo hermenêutico e o descaso pelas fontes demonstrados por Erich Fromm e Bruno Bettelheim, entre outros, em seus escritos sobre os contos de fadas. Assim ocorre, por exemplo, em "Chapeuzinho Vermelho", que teve a sua narrativa original amplamente modificada. A versão original desse conto, narrada por camponeses em suas cabanas, durante os serões realizados em torno de suas lareiras, nas longas noites de inverno, apresenta episódios de canibalismo e de estupro, sem menção ao símbolo de menstruação (o chapeuzinho vermelho) e à garrafa que a menina levava, simbolizando a virgindade. $\mathrm{O}$ autor desmistifica personagens e episódios inexistentes na versão original e deturpadas em narrativas subsequentes, nas quais o lobo aparece como o macho estuprador, e

[...] as duas (inexistentes) pedras colocadas na barriga do lobo, depois que o (inexistente) caçador retira a menina e sua avó, representam a esterilidade, a punição por infringir um tabu sexual. Assim, com uma misteriosa sensibilidade para detalhes que não apareciam no conto original, o 
psicanalista nos conduz para um universo mental que nunca existiu ou, pelo menos, que não existia antes do advento da psicanálise. (DARNTON, 1986, p. 23).

A moral da história original, sem os acréscimos posteriores, seria, para as meninas, afastarem-se dos lobos; para os historiadores, transcrever o universo mental dos camponeses, no início da Modernidade (DARNTON, 1986, p. 22). De fato, para os historiadores, os contos são documentos históricos, que surgiram ao longo de muitos séculos, sofrendo diferentes mutações em tradições culturais diferentes, sugerindo as mudanças das mentalidades em contextos diversos. A razão para o uso descuidado de fontes pelos psicanalistas seria proveniente do deslocamento da "aterrorizante irracionalidade, que parece deslocada na Idade da Razão", que teria levado Grimm e Perrault, Fromm e Bettelheim a omitirem "o ato de canibalismo com a avó e o strip-tease antes de a menina ser devorada", demonstrando que "os camponeses não precisaram de um código secreto para falar sobre tabus" (DARNTON, 1986, pp. 26-27).

As mesmas características de pesadelo aparecem nas outras histórias: assassinatos, estupros, incestos, sodomia, canibalismo. O mundo retratado pelos contadores de histórias do século XVIII era de brutalidade nua e crua, sem mensagens ocultas por símbolos. O recurso à antropologia e ao folclore é essencial para o entendimento dessas histórias, pois essas disciplinas possuem técnicas que relacionam os contos com a arte de narrar histórias e com o contexto no qual as narrativas ocorrem, investigando estilos culturais através da universalidade do motivo.

À análise psicanalítica de Bruno Bettelheim, soma-se, como uma espécie de subcategoria, o gênero de autoajuda que considera que o sucesso dos "contos de fadas" decorreria de estarem neles gravadas

\begin{abstract}
ideias infinitamente sábias que durante séculos se recusaram a se deixar mutilar, desgastar ou matar. As ideias mais persistentes e sábias estão reunidas nas teias de prata a que chamamos contos. Desde a descoberta do fogo, os seres humanos se sentem atraídos pelos contos místicos. Por quê? Porque apontam para um fato importante: embora a alma em sua viagem possa tropeçar ou se perder, no fim ela reencontrará seu coração, sua natureza divina, sua força, seu caminho para Deus em meio à floresta sombria - ainda que leve vários episódios ou "dois passos à frente e um atrás" para descobri-los e recuperá-los. (ESTÉS, 2005, p. 11).
\end{abstract}

Os efeitos terapêuticos apontados pela hermenêutica acima apresentam-se em análises pertinentes ao imaginário narrativo da contemporaneidade, demonstrando permanências e mudanças possíveis dos contos medievais na atualidade. Como vimos, a Idade Média criou narrativas imaginárias destinadas a alimentar sonhos/pesadelos de longa duração, na maior parte das vezes por meio da sublimação das realidades sociais e materiais daquela época.

\title{
5 O fantástico nas narrativas literárias do século XIX
}

As narrativas contadas por camponeses, em alguns de seus aspectos, podem ser reencontradas em avatares do imaginário fantástico oitocentista. Nos contos do século XIX, 
os emblemas que estruturam a realidade ajustam-se ao contexto das grandes cidades, em que os homens esbarram uns nos outros cotidianamente, cada qual lidando sozinho com os seus fantasmas em meio a toda gente que o cerca. O conflito parece não ser mais entre o homem e a natureza ameaçadora que rondava as aldeias, universo em que a ameaça se concretizava por meio de imagens zoomórficas. Desse modo, o drama desloca-se para o interior do indivíduo, como projeção dos avanços da medicina no psiquismo, do qual tentava entender as estruturas a fim de melhorar o tratamento das doenças mentais. Nesse mesmo ambiente, a ciência é idealizada como positiva, provindo daí o Positivismo, por meio do qual o homem deveria transformar-se em mero observador da Natureza, descobrindo as suas leis, físicas ou sociológicas. A experimentação passou, portanto, a basear-se no olhar.

Nesse sentido, vale destacar a presença do olhar, talvez o mais concreto dos sentidos e aquele que lastreia o cientificismo do século XIX, pautado na observação e na experimentação, como podemos observar no conto de Edgar Allan Poe, O coração denunciador (CALVINO, 2004, pp. 279-284). Nele, a imagem central do olho da vítima, imagem obsessivamente apresentada pelo fluxo de consciência do narrador assassino, como sinédoque daquilo que quer matar - o velho, que emblematiza, por sua vez, os fantasmas que perseguem o criminoso. $\mathrm{O}$ mais cruel desses fantasmas parece ser a dúvida que o apavora: saber se está ou não louco, dúvida esta materializada nas recorrentes interpelações que faz ao leitor, o interlocutor oculto do trecho abaixo:

mas por que você diria que estou louco? [...] Como posso estar louco? [...] Você me imagina louco. Loucos não sabem de nada. Eu não lhe disse que você confunde loucura com um simples aguçamento dos sentidos? [...] Se você ainda pensa que sou louco vai mudar de ideia depois de eu descrever as sábias precauções que tomei para ocultar o corpo (POE, in: CALVINO, 2004, p. 279 e 282).

O limiar entre a insanidade e a razão é construído na narrativa pela imagem do raio tênue de luz que atravessa a escuridão do quarto para iluminar o "olho do abutre", o "ponto maldito", que é o olho do velho assustado com a presença do algoz no quarto: "todo ele [o olho] azul-pálido coberto por um véu horrendo que enregelou a própria medula em meus ossos" (POE, in: CALVINO, 2004, p. 282), revela-nos o fluxo de consciência do narrador.

Na sequência da narrativa, o limiar entre a insanidade e a razão perdura e é construído por meio da encenação, espécie de espetáculo - que novamente remete ao ato de olhar -, que o assassino empreende quando recebe os policiais em casa no dia seguinte ao assassinato do velho. Friamente, depois de um tour pelo cenário do crime que ele cuidadosamente limpara, acomoda os investigadores em uma cadeira e posiciona-se frente a eles, sobre o cadáver retalhado do velho, que escondera debaixo do assoalho. Nesse ato, uma compulsão suicida provoca a sua confissão, encenada como um ato de normalidade, realizado "na audácia selvagem da minha completa vitória” (POE, in: CALVINO, 2004, p. 283). Essa estratégia, curiosamente, desconstrói-se quando o ruído do coração do velho morto, ouvido só pelo narrador, leva-o a confessar o seu crime aos policiais: o que os olhos não veem concretamente, o ruído alucinatório do coração da vítima revela aos investigadores-espectadores (que, ao fim ou 
ao cabo, não sabemos sequer se são ou não produtos do delírio do assassino). $O$ insólito aqui se constrói, portanto, nos limites entre razão e loucura, mediados pela imagem do olho e tecidos na ficcionalidade do fantástico.

O olhar faz-se presente também na narrativa "A Noite", de Guy de Maupassant, em que o narrador é uma personagem notívaga, a perambular por uma Paris mal iluminada. Apesar de declarar, no início da narrativa, que o dia lhe provoca cansaço, que ama a noite com todos os sentidos e "com os meus olhos que a veem", no final do conto, depois de percorrer o cenário desértico da capital, clama pelo dia que demora, andando "como um cego", tateando os muros com a bengala e levantando "os olhos para os céus esperando que o dia raiasse", num espaço "todo negro, mais profundamente negro que a cidade" (MAUPASSANT, in: CALVINO, 2004, pp. 351, 354 e 355). O périplo noturno inicia-se sob a perspectiva da razão, pois o personagem caminha por lugares geograficamente demarcados (Champs-Elysées, Arco do Triunfo, Bois de Bologne, rua Royale, a Bastilha, entre outros). Paulatinamente, ainda que o espaço continue sendo demarcado - a última referência é ao Halles - o tempo torna-se menos mensurável: primeiro, o personagem não consegue enxergar as horas no relógio, apenas ouvir-lhe o tiquetaque e depois o próprio relógio para de funcionar, assim como os relógios dos campanários e dos monumentos. Por fim, a própria narrativa, bem como o narrador diluem-se: a narrativa, nas reticências e o narrador, nas águas do Sena, quando decide mergulhar no rio:

O Sena ainda corria? Quis saber, encontrei a escada, desci... Eu não ouvia a torrente encapelando sob os arcos da ponte... Mais degraus... depois, areia... lama... depois a água...molhei meu braço...ele corria...frio...frio...frio...quase gelado...quase seco...quase morto... (MAUPASSANT, in: CALVINO, 2004, p. $355)$.

À medida que a escuridão da noite recrudesce, a cegueira obscurece a visão, o tempo relativiza-se e o espaço sólido da cidade é substituído pelo espaço líquido e insólito do rio, em que tudo se dilui no fluxo das águas a que o narrador se entrega: "E senti perfeitamente bem que nunca mais teria força para subir de novo... e que ia morrer ali... eu também, de fome, de cansaço, e de frio." (MAUPASSANT, in: CALVINO, 2004, p. 355). O ponto final que sucede a esta última oração, em um período marcado por reticências, sugere, para além da referência explícita à morte, a autoaniquilação do narrador. $\mathrm{O}$ insólito aqui se constrói nos limites entre o mundo exterior racional e o mundo interior caótico, também mediado pela perda da capacidade de ver. Se no conto de Poe, o mediador entre a razão e a loucura é o olhar, que mesmo ausente provoca a manifestação do crime cometido, por meio do ruído delirante que perseguia a assassino, no conto A Noite o mediador entre a razão e o caos configura-se na visão da cidade que, à medida que desaparece, leva com ela o tempo e faz manifestar-se a evidência por meio do tato, a necessidade de o sujeito sentir a fluidez abstrata do tempo congelado por meio da fluidez concreta do rio.

Cabe destacar que o périplo do narrador pela cidade remete-nos a uma espécie de viagem simbólica, imagem tanto de uma viagem espacial quanto temporal, símbolo da visão ao mesmo tempo fantástica e fantasmagórica da fluidez da existência sem luz numa era em que, pretensamente, a humanidade vivia entusiasmada com a luz do método científico que buscava 
iluminar todos os fenômenos.

O olho sem pálpebra, de Philarète Chasles (In: CALVINO, 2004, pp. 121-137), constitui outra narrativa em que o olho e o ato de olhar apresentam-se como chaves de leitura, já a partir do título. Trata-se da história de Muirland, que provocara a morte de sua primeira esposa por ciúmes. A história nos é contada em uma noite de Halloween, em um ambiente repleto de superstições, seres mágicos e rituais em que os jovens buscam em meio à natureza, repleta de seres feéricos, vaticínios para que revelem o futuro parceiro e como será o matrimônio. Muirland participa de tudo, mas sempre reafirmando que não quer se casar novamente, uma vez que é ciumento e, ao se tornar marido, suas pálpebras negam-se a fechar para vigiar a esposa. Ainda assim, porque os jovens que estão com ele não querem participar do ritual, Muirland decide-se a se colocar diante de um espelho, com uma vela, evocando a figura da futura mulher, cujo vulto apareceu refletido no espelho, sobre o seu ombro. Muirland casa-se com a mulher misteriosa que lhe apareceu, numa cerimônia insólita, realizada no plano onírico, num primeiro momento, mas que se materializa quando ele acorda e vê-se casado com a jovem Spellie, que "possuía todas as características daquele ser sobrenatural [do espectro com quem se casara no sonho], mal e mal modificadas e como que suavizadas". O detalhe mais aterrador é que, não obstante à beleza da esposa, ele percebe que ela não tinha pálpebras que cercassem as "grandes órbitas de um azul escuro [que se] desenhavam sob o arco preto da sobrancelha" (CHASLES, in: CALVINO, 2004, p. 133), fato só percebido pelo marido.

A partir desse momento, os olhos da mulher, os mesmos que inspiravam baladas aos poetas do cantão onde o casal residia, não dão mais sossego à personagem, a ponto de Muirland atravessar o oceano e fugir para as florestas da América do Norte. Aí, vem a conhecer e a se tornar amigo de um chefe nativo, do qual acaba por receber a filha em casamento. Pouco tempo depois, volta a sentir o olho sem pálpebra da mulher que deixara na Europa, e "viu a onda clara e pura do Ohio, e ali se jogou, aterrorizado". O narrador termina a história desvelando didaticamente a alegoria do olho sem pálpebra como sendo a imagem do "olho sempre aberto da mulher ciumenta, o mais terrível dos suplícios" (CHASLES, in: CALVINO, 2004, p. 137). O texto faz destacar, na constelação de imagens insólitas que usa, os limites sempre tênues entre a trajetória real de Muirland e as lendas e as superstições escocesas. Estas, a seu turno, reproduzem os limites entre certa incredulidade inicial da personagem e a infiltração abrupta do mundo mágico em sua vida. Os limites entre o real e o fantástico, mais uma vez, são mediados pelo olhar reforçado pela imagem central do espelho no conto, espécie de portal que promove o amálgama entre o real e o insólito.

$\mathrm{Na}$ narrativa $\mathrm{O}$ homem de areia, de Ernest Theodor Amadeus Hoffman (HOFFMAN, in: CALVINO, 2004, pp. 50-81), encontramos o personagem Natanael obcecado pela imagem do monstro que a mãe inventara, quando ele era criança, para fazê-lo dormir. A estranha figura fantasmagórica que arranca os olhos das crianças à noite é vista na figura misteriosa do advogado Coppellius, a quem o narrador atribui a morte de seu pai e quem, anos depois, ele reconhece em Coppola, um vendedor de barômetros e lentes que o procura.

Efetivamente, ao longo da narrativa, o ogro inventado pela mãe cega Natanael, a ponto de ele não conseguir enxergar que a sua amada, Olímpia, é um autômato criado por certo professor, Spallanzani, ainda que todos os amigos digam que Olímpia "poderia ser considerada 
linda se ao seu olhar não faltasse o brilho da vida, quer dizer, se não lhe faltasse o sentido da visão. Seu olhar é estranhamente contido, cada movimento parece depender de um maquinismo de corda." (HOFFMAN in CALVINO, 2004, p. 74).

A farsa só é descoberta por Natanael quando testemunha a briga entre Spallanzani e Coppola (ou Coppelius, ou o Homem de Areia) pela posse do autômato. Do ser artificial em pedaços, sobram os olhos que Spallanzani confessa ter roubado de Natanael, quando o incita a perseguir Coppola, que fugira com o autômato:

Atrás dele, atrás dele! Que estás esperando? Coppelius... Coppelius... Ele roubou o meu melhor autômato... vinte anos de trabalho... eu me dediquei de corpo e alma... O maquinismo, a fala, o andar...é tudo meu. Os olhos...os olhos, eu os roubei de ti...maldito...desgraçado...Atrás dele! Vai buscar a minha Olímpia. Aqui estão os olhos (HOFFMAN, in: CALVINO, 2004, p. 77).

O contato com os olhos de Olímpia, que são, supostamente, os seus próprios olhos, faz com que Natanael perca a razão e seja internado em um manicômio.

Tempos depois, Natanael aparentemente se recupera e reencontra Clara, a noiva a quem esquecera por conta da paixão cega que desenvolvera por Olímpia. A felicidade do casal dura pouco tempo, pois basta que Natanael reveja os olhos de Clara, por meio da luneta que comprara de Copolla, para que o delírio retorne e que ele confunda a amada com Olímpia e tente jogá-la do alto de uma torre. Impedido pelo seu amigo e irmão de Clara, Lotário, Natanael acaba por se jogar de uma torre, diante de um ajuntamento de curiosos entre os quais se encontra o "gigantesco advogado Coppelius", a quem Natanael percebe do alto e dirige o seu último "berro estridente: "Ê, lindos olhos... lindos olhos!" (HOFFMAN, in: CALVINO, 2004, p. 81).

Nesta narrativa, a imagem do olho divide o espaço com a metáfora da loucura. Assim como nos contos $\mathrm{O}$ coração denunciador e $\mathrm{O}$ olho sem pálpebra, é a necessidade de fugir tanto do olhar do outro quanto do seu próprio olhar que leva o protagonista à aniquilação. Também nas três narrativas, bem como em A noite, a perda da razão instaura-se a partir dos dilemas que o olho e a visão ou a ausência dela impõem às personagens. $\mathrm{O}$ olho denuncia, persegue, engana ou torna-se inútil na escuridão.

$O$ olho que condena também é imagem central no conto $O$ elixir da longa vida, de Honoré de Balzac (BALZAC, in: CALVINO, 2004, pp. 102-120). O jovem Don Juan Belvidero vive em meio ao luxo e ao prazer propiciados pelo pai nonagenário, o qual, ao sentir a proximidade da morte, pede ao filho que use certo elixir para ressuscitá-lo. O jovem, ao perceber o poder do elixir, busca economizá-lo para um uso pessoal no futuro, traindo o seu pai e banhando apenas um de seus olhos. E "o olho cheio de vida, um olho de criança numa caveira", ressurge no rosto do ancião, um olho flamejante que "parecia querer se atirar sobre Don Juan, e pensava, acusava, condenava, julgava, falava, gritava, mordia" (BALZAC. in: CALVINO, 2004, p. 110). Don Juan, sozinho diante do corpo do pai, "reunindo toda coragem necessária para ser covarde, esmagou o olho, apertando-o com um pano, mas sem olhá-lo" (BALZAC, in: CALVINO, 2004, p. 111). Contudo, à vista da sociedade, passa-se por um filho 
piedoso, homenageando o pai com um túmulo suntuoso e com imagens executadas por artistas famosos da época.

Já velho, depois de levar uma vida egocêntrica em que "o universo era ele mesmo", a história se repete. Don Juan pede ao filho que o banhe com o elixir milagroso após a sua morte. Obediente ao pai, o filho, Don Felipe Belvidero, começa a esfregar o seu cadáver com o elixir, circunstância em que o braço do cadáver volta à vida, apertando-lhe o pescoço. A cabeça de Don Juan, umedecida pelo elixir, tornara-se "tão jovem, tão bela como a de Antinoo" a ponto de ser exposta como um milagre no centro da catedral (BALZAC, in: CALVINO, 2004, p. 111). Para celebrar o milagre, a cabeça inconformada de Don Juan é exposta durante a cerimônia de canonização e consegue escapar do relicário, devorando a cabeça do abade que oficiava a cerimônia.

O que só os olhos de Bartolomeu presenciaram é revelado os olhos de todos que se encontravam na catedral, quando o profano candidato a santo devora o crânio profano do abade, que só quis canonizar Don Juan para aumentar as suas próprias rendas e talvez para se apoderar da viúva dele, D. Elvira. A suposta possibilidade de um remédio para a cura de todos os males, isto é, o elixir da longa vida procurado pelos alquimistas medievais e pelos homens de ciência do século XIX, parece estar emblematizada no elixir eficiente, mas escasso, que sugere o fracasso de se alcançar uma panaceia universal.

A última narrativa a compor esta análise intitula-se Em terra de cego, de Herbert George Wells, (WELLS, in: CALVINO, 2004, pp. 494-517). Nela, um aventureiro perdido nos Andes, Nuñez, chega a uma terra em que, há gerações, todos tinham perdido a visão. A aparente vantagem do ditado popular, "em terra de cego, quem tem um olho é rei", não se confirma. $\mathrm{O}$ estranho dom de ver do estrangeiro, desconhecido dos habitantes da terra, é interpretado como doença. Aliás, uma doença que dá menos vantagens ao vidente, pois os cegos desenvolveram outras formas de percepção. Quem desvenda o mistério é o médico da tribo:

Essas estranhas coisas que chamamos os olhos, e que existem para fazer uma
depressão macia e agradável no rosto, são doentes, no caso de Bogotá [que é
como chamam o estrangeiro por ele ter dito que veio de Bogotá], de uma
maneira tal que afeta seu cérebro. São excessivamente estendidas, ele tem
cílios e suas pálpebras se movem, e consequentemente seu cérebro está num
estado de constante irritação e distração. (WELLS, in: CALVINO, 2004, p.
513).

Logo, a cura, condição para que ele possa casar-se com Medina-saroté, cidadã da tribo por quem se apaixonara, seria uma cirurgia para "extrair esses corpos irritantes" (WELLS, in: CALVINO, 2004, p. 513), que são os olhos. Ainda que tenha cogitado em se submeter à perda da visão, no final da narrativa, o estrangeiro resolve fugir escalando a mesma montanha que usara para chegar ao vale.

O caráter insólito desta narrativa, que encerra a coletânea, além de questionar a primazia da visão, sentido privilegiado pelo método científico da observação e da experimentação, coloca-a, ironicamente, como causa da doença que será eliminada graças à ciência dos cegos. Entre perder a visão e ganhar o amor, o herói decide conservar os seus olhos. 
Embora a imaginação dos homens medieval e oitocentista integrasse uma teia mágicoreligiosa comum, essa teia possui variedades significativas para uma exegese fundamentada na literatura e na história. Dos pontos de vista da produção dos contos medievais e oitocentistas, observam-se as condições em que foram elaborados, a identidade de seus autores e os fins a que se destinavam. Para os primeiros, trata-se de uma produção popular, com uso de uma linguagem direta e objetiva. As narrativas limitam-se aos fatos sem o uso de palavras floreadas ou circunstâncias indiretas. Destinavam-se a transmitir estratégias de sobrevivência aos ouvintes formados por camponeses analfabetos. Analfabetos, provavelmente, eram também os seus autores. A oralidade apresenta-se no estilo empregado e os contos eram narrados com auxílio de ruídos produzidos pelo narrador.

Para os contos fantásticos do século XIX, os seus autores já não eram camponeses analfabetos, mas sim literatos da pequena e média burguesias, que escreviam para leitores interessados no estilo e tema por eles adotados. Temos, assim, uma produção literária inserida em objetivos comerciais da imprensa, que procurava atender aos desejos de seus leitores.

Cenários e personagens também são discrepantes, apesar de descreverem realidades transpostas para o imaginário. Os finais dos contos de fadas, por princípio, são felizes, pois as forças sobrenaturais atuam em favor das personagens principais. Ao contrário, os contos do século XIX têm finais infelizes, com os seus heróis destroçados moral, psíquica e fisicamente. Neles projetam-se os estilos da época, transtornada pelas profundas revoluções materiais e espirituais, que se seguiram à Revolução Industrial de meados do século XVIII.

As circunstâncias dramáticas usadas pelos contos de uma e de outra época assemelhamse: o amor, o dinheiro e a morte constituem os dramas centrais em que gravitam as personagens.

\section{Considerações finais}

As narrativas medievais possuem muitos elementos que falam da vida cotidiana nos campos e nas aldeias. O efeito do real é incontestável nessas narrativas, com o mundo de pessoas deslocadas de suas casas pela miséria. Horizontalmente, os contos de fadas inscrevem-se no modelo geral que subentende toda obra de ficção dramática das classes populares. $\mathrm{O}$ problema central, que se pode colocar no coração desse modelo, apresenta-se da seguinte forma: como sobreviver, quando se é pobre ou miserável, em uma sociedade dominada pelos barões. Mais precisamente, como um jovem totalmente desprovido de capitais, a não ser aqueles identificados com seus dotes naturais, encontraria dinheiro, terras e alimento para encontrar alguém para desposar, recolhendo, para esse fim, o consentimento preliminar do pai da moça ou de sua linhagem, e eliminando, subsidiariamente, um rival. As respostas a essas questões inserem-se em um segundo modelo ou conjunto cultural: o herói, usando de um pacto com um determinado ser sobrenatural, consegue reunir os capitais que lhe permitirão resolver os seus problemas. Problemas não especiais de um indivíduo, mas da cultura camponesa em geral, cujas soluções perfazem estratégias claras de sobrevivência e mostram, às avessas, desejos inconcebíveis de alcançar por pessoas incluídas nos segmentos inferiores da população. Portanto, extravasam os limites do entretenimento para apresentar uma tentativa de sublevação 
da gente humilde a seus destinos de classe.

Já no mundo dominado pelo Positivismo do século XIX, os questionamentos são de outra ordem. Sob o signo do individualismo, o fantástico procura respostas gerais da época por meio de personagens transpostas para um universo metafísico, que não se vê, mas pode ser submetido a uma análise simbólica, transfiguradora da realidade. Neste cenário, apresenta-se o dilema de conciliar as imagens de uma floresta nada racional, situada em nossa memória, com a realidade objetiva das grandes cidades. No mesmo sentido, apresenta-se a questão de acomodar o maior mito do capitalismo, o individualismo, de uma sociedade industrial baseada na concentração de capitais, de máquinas e de homens, com os ideais humanistas que colocavam o homem como o centro do universo. A resposta aparece estilhaçada nos contos fantásticos, com homens convivendo com o insólito de personagens estranhos ou de situações fantasmagóricas.

A análise das narrativas que têm o fantástico como tema central parece sugerir que o homem atual encontra-se desamparado por haver perdido seus vínculos com o sobrenatural, que ainda persistem em seu interior, como reflexos de uma idade perdida. Não há mais como pactuar, racionalmente, com seres sobrenaturais. Daí talvez a presença da loucura nos textos, como estratégias para se aceder a um mundo desparecido. Também os problemas deixaram de ser coletivos e cada vez mais se atêm à esfera do indivíduo, mostrando-se, em grande parte, insolúveis. Talvez os contos fantásticos, ao extravasarem os limites do entretenimento, apresentem uma tentativa de sublevação do homem contra o excesso de razão do universo globalizado. Os contos medievais, por sua vez, representam uma sublevação à sociedade de ordens que submergia servos e vilões na miséria, na fome e na doença.

\section{Referências:}

BALZAC, H. O Elixir da longa vida. In: CALVINO, Í. Os Contos fantásticos do século XIX. São Paulo: Companhia das Letras, 2004.

CALVINO, Í. Os Contos fantásticos do século XIX. São Paulo: Companhia das Letras, 2004.

CHASLES, P. O Olho sem pálpebra. In: CALVINO, Í. Os Contos fantásticos do século XIX.São Paulo: Companhia das Letras, 2004.

KAPPLER, C. Monstres, démons et merveilles à la fin du Moyen Age. Paris: Payot, 1980.

DARNTON, R. O grande massacre de gatos, e ouros episódios da história cultural francesa; tradução de Sônia Coutinho. Rio de Janeiro: Graal, 1986.

DARNTON, R. Os best-sellers proibidos da França pré-revolucionária. Tradução de Hildegard Feis. São Paulo: Companhia das Letras, 1998.

DELUMEAU, J. História do Medo no Ocidente. São Paulo: Companhia das Letras, 2009.

ESTÉS, C. P. Prefácio. In: GRIMM, J. Contos dos Irmãos Grimm/organizado, selecionado e prefaciado pela Dra. Clarissa Pinkola Estés. Rio de Janeiro: Rocco, 2005.

GOMES, Á. C. A Lógica do Delírio. In: GOMES, Á. C. et al. (orgs.) A literatura e o imaginário: diálogos transversais. Curitiba: CRV, 2017.

HOFFMAN, E. T. A. W. O homem de areia. In: CALVINO, Í. Os Contos fantásticos do século 
XIX. São Paulo: Companhia das Letras, 2004.

LE GOFF, J. Maravilhas. In: Dicionário temático do Ocidente Medieval. Bauru, SP: Edusc; São Paulo, SP: Imprensa Oficial do Estado, 2002. v.2.

LE GOFF, J. Heróis e maravilhas da Idade Média; tradução de Stephania Matousek. Petrópolis, RJ: Vozes, 2009.

LE GOFF, J. (org.). Homens e mulheres da Idade Média /organização Jacques Le Goff; tradução Nícia Adan Bonatti. 1. ed. São Paulo: Estação Liberdade, 2013.

MAUPASSANT, G. A Noite. In: CALVINO, Í. Os Contos fantásticos do século XIX. São Paulo: Companhia das Letras, 2004.

PAES, J. P. Gregos \& Baianos. São Paulo: Brasiliense, 1985.

POE, E. A. O Coração denunciador. In: CALVINO, Í. Os Contos fantásticos do século XIX. São Paulo: Companhia das Letras, 2004.

ROBIN, R. Histoire et linguistique. Paris: Librairie Armand Colin, 1973.

WELLS, H. G. Em terra de cego. In: CALVINO, Í. Os Contos fantásticos do século XIX. São Paulo: Companhia das Letras, 2004. p.419-517.

Recebido em: 28/10/2019

Aceito em: 09/01/2020 